\title{
Evaluation of Selected Bacterial Endophytes for Biocontrol Potential against Phytophthora Blight of Bell Pepper (Capsicum annuum L.)
} Irabor $\mathbf{A}$ and Mmbaga MT* $^{*}$

Department of Agricultural and Environmental Sciences, College of Agriculture, Human and Natural Sciences, Tennessee State University, Nashville, TN, USA

\begin{abstract}
Phytophthora blight, caused by Phytophthora capsici, is the most destructive disease of bell pepper in the United States. The effectiveness of current management strategies is limited by the long-term survival of oospores, wide host range, aggressive fungicide-resistant isolates, and lack of resistant cultivars with acceptable agronomic traits. Biological control is a viable alternative, and the use of endophytic microorganisms as biological control agents $(B C A)$ has attracted widespread attention because they colonize the same ecological niches as plant pathogens. Seven isolates of bacterial endophytes in three genera Serratia (B17B), Enterobacter (E), and Bacillus (IMC8, Y, Ps, Psl and Prt), isolated from papaya, snap bean and flowering dogwood were evaluated for effects on $P$. capsici mycelial growth in vitro, and on disease severity and plant growth in greenhouse environment. All isolates significantly inhibited the mycelial growth of $P$. capsici with Ps, Psl and Prt having superior inhibitory effects. Seed treatments with Ps, Psl and Prt followed by plant inoculation with P. capsici reduced disease severity, and significantly increased plant shoot height, fresh weight, and fruit yield (number and weight) with Ps and Prt being slightly superior to Psl. Compatibility tests between isolates showed that only B17B and $Y$ were compatible with each other. Sensitivity tests to different levels of mefenoxam (Ridomil Gold SL) showed that Ps, Psl and Prt were tolerant to the fungicide, while $P$. capsici was highly sensitive. Thus, Ps, Psl and Prt can be used in rotation with mefenoxam to reduce the frequency of fungicide usage for a more environmentally friendly, long lasting, consistent, and effective control of phytophthora blight. Overall, all isolates tested are potential BCAs against $P$. capsici, but more greenhouse and field studies are required to confirm in vitro results for all isolates that showed good potential in in vitro studies.
\end{abstract}

Keywords: Phytophthora capsici; Soil-borne pathogens; Fungicide resistance; Biological-based IPM; Vegetable diseases

\section{Introduction}

Bell pepper (Capsicum annuum L.) is one of the most important vegetable crops in the world [1-4]. The crop thrives best under warm climatic conditions which also favor the development of many plant diseases. Disease constitutes one of the major constraints affecting commercial pepper production in the United States. Phytophthora blight, caused by Phytophthora capsici, is a widespread and highly destructive disease of peppers in tropical, subtropical, and temperate regions of the world [5]. It is especially important in the southern and southeastern United States where warm temperatures, high relative humidity and frequent rainfall promote rapid disease development [3].

In recent years, Phytophthora blight has become the most prominent disease of peppers in the United States [3,6]; total crop losses from $P$. capsici root rot can occur under wet conditions [6]. The wide host range of $P$. capsici consists of more than 45 species of crops and weeds belonging to 14 families [7-10]. The pathogen is a heterothallic, soil-borne oomycete (water-mold) characterized by asexually produced motile, biflagellate zoospores and sexually produced thick-walled oospores. The pathogen can survive for several years in the soil in the form of oospores even in the absence of susceptible crops and initiate infection when a host plant becomes available. The pathogen infects the entire plant causing symptoms such as foliar blight, stem canker, fruit, crown, and root rots $[3,7,11]$. Disease development is favored by warm temperatures, high rainfall or irrigation, and poor soil drainage [8]. The disease is managed mainly by crop rotation, application of chemical fungicides such as metalaxyl or mefenoxam, and management of irrigation water [12-15]. However, it is difficult to manage Phytophthora diseases because of the long-term survival of oospores in the soil, wide host range, and long-distance movement of the pathogens through soil and water [6,7]. Lack of resistant crop varieties with acceptable agronomic traits $[16,17]$, and the rise of new aggressive phytophthora strains resistant to chemical fungicides [6] are additional challenges for the management of phytophthora blight in vegetables. Furthermore, the indiscriminate use of chemical pesticides is raising concerns due to their toxicity hazards on human health and the environment $[18,19]$. These concerns have led to the phase-out of some chemical fungicides such as the ozone-depleting soil fumigant methyl bromide [20]. Therefore, there is a need for more effective, sustainable, and environmentally friendly management strategies for phytophthora blight.

Biological control is a viable alternative for plant disease management especially as a component of an integrated disease management program $[19,21,22]$. Biological control agents antagonize pathogens directly by hyperparasitism, predation, and production of antibiotics and lytic enzymes; and indirectly by competing for space and nutrients, inducing systemic resistance, and promoting plant growth [18,19,23,24]. Several fungal and bacterial BCAs have been shown to be effective against many pathogens of peppers $[16,25]$. However, commercially available biocontrol agent for the management of Phytophthora blight are needed; continued search for effective BCAs will benefit crop production and especially benefit organic farming systems. The success of biological control is often dependent on the ability of the BCA to colonize the host

*Corresponding author: Mmbaga MT, Department of Agricultural and Environmental Sciences, College of Agriculture, Human and Natural Sciences, Tennessee State University, Nashville, TN, USA, Tel: +1 (615) 6535223; E-mail: mmmbaga@tnstate.edu

Received October 04, 2017; Accepted October 23, 2017; Published October 25 2017

Citation: Irabor A, Mmbaga MT (2017) Evaluation of Selected Bacterial Endophytes for Biocontrol Potential against Phytophthora Blight of Bell Pepper (Capsicum annuum L.) J Plant Pathol Microbiol 8: 424. doi: 10.4172/2157-7471.1000424

Copyright: (c) 2017 Irabor A, et al. This is an open-access article distributed under the terms of the Creative Commons Attribution License, which permits unrestricted use, distribution, and reproduction in any medium, provided the original author and source are credited. 
plant tissues $[18,26,27]$ and endophytes may provide valuable natural resources.

Endophytes are fungi and/or bacteria which asymptomatically inhabit the internal tissues of plants [28]; they colonize the same ecological niches as disease-causing organisms [29,30]. Many are known to form mutually beneficial associations with their hosts and play roles essential in plant survival; some promote plant growth, induce plant defense mechanisms, and reduce disease severity, protect plants against herbivory, fix atmospheric nitrogen and increase mineral nutrient uptake [31-34]. Endophytes are ubiquitous, and every plant studied to date harbors at least one or more endophytic microbial species [30,33,35]. Antagonistic effects of bacterial endophytes on various pathogens of agriculturally important crops have been demonstrated [36-38]. However, the complexity of microbial interactions in natural environments is not well understood and search for biocontrol agents that are adequately effective in field applications remains important.

The objectives of this study were to screen endophytes isolated from flowering dogwood, snap bean, and papaya for biocontrol activities against $P$. capsici, evaluate the compatibility between bacterial endophytes, and compatibility of selected isolates with fungicide mefenoxam that is commonly used to control P. capsici.

\section{Materials and Methods}

\section{Pathogens, bacterial isolates, and culture conditions}

Isolates of $P$. capsici from infected pepper plants were previously isolated using PARP (pentachloronitrobenzene, ampicillin, rifampicin and pimaricin)-amended V8 juice agar media [39] and maintained on potato dextrose agar (PDA) or clarified $\mathrm{V}^{\circ}$ juice agar media $(\mathrm{cV} 8,800$ $\mathrm{ml}$ distilled water, $200 \mathrm{ml}$ of clarified V8 juice, $2 \mathrm{~g}$ of $\mathrm{CaCO}_{3}$, and $15 \mathrm{~g}$ of bacteriological agar); short-term culture storage was done at $4 \pm 2^{\circ} \mathrm{C}$. Phytophthora cultures used in this study were 7 to 10 days-old, grown in PDA or V8 agar at $28 \pm 2^{\circ} \mathrm{C}$. Bacterial endophytes used in this study (Table 1) were previously isolated from flowering dogwood, snap bean and papaya, maintained on nutrient agar (NA) or Luria-Bertani (LB) agar media, and stored at $-80^{\circ} \mathrm{C}$; fresh $24 \mathrm{~h}$-old cultures grown at $28 \pm$ $2^{\circ} \mathrm{C}$ were used for this study.

\section{In vitro evaluation of bacterial endophytes for bioactivity against $P$. capsici}

Dual culture assays were conducted to evaluate the inhibitory effects of the endophytes on the mycelial growth of $P$. capsici on nutrient agar (NA) and Luria-Bertani (LB) agar. Growth media for dual culture assays consisted of equal parts of PDA and NA or LB to facilitate the growth of the pathogen as well as the bacterial endophyte. A 5-mm mycelial plug cut from the actively growing margins of $P$. capsici cultures grown on PDA was placed at the centre of an $85-\mathrm{mm}$ Petri dish containing PDANA/LB (1:1) growth media. Four 5-mm plugs of the test endophyte grown on LB or NA were placed at equidistant positions $(2.75 \mathrm{~cm})$ from the pathogen. Pathogen control plates consisted of the pathogen plug

\begin{tabular}{|c|c|c|}
\hline Isolates & Endophytes & Plant source \\
\hline B17B & Serratia marcescens & Dogwood stem \\
\hline E & Enterobacter sp & Snap bean root \\
\hline IMC8 & Bacillus thuringiensis & Dogwood stem \\
\hline Y & B. thuringiensis & Dogwood stem \\
\hline Ps & B. vallismortis & Papaya stem \\
\hline Psl & B. amyloliquefaciens & Papaya stem \\
\hline Prt & B. subtilis & Papaya root \\
\hline
\end{tabular}

Table 1: Bacterial endophytes and their sources. with LB or NA plugs, while the BCA control plates consisted of four BCA plugs with a PDA plug. Each treatment had four replicates. The plates were placed in an inverted position in an Isotemp $\mathrm{p}^{\mathrm{m}}$ incubator (Fisher Scientific ${ }^{\mathrm{m}}$, Waltham, MA 02451, USA) at $25 \pm 2^{\circ} \mathrm{C}$ and observed for mycelial growth. At day 7 , the mycelial radius was measured and $P$. capsici growth inhibition was calculated using the formula;

$\%$ Growth inhibition $=\mathrm{R}_{2}-\mathrm{R}_{1} / \mathrm{R}_{2} \times 100$

where, $\mathrm{R}_{2}=P$. capsici mycelial radius in control plate $(\mathrm{cm}), \mathrm{R}_{1}=P$. capsici mycelial radius in pathogen-BCA dual culture $(\mathrm{cm})$

\section{Compatibility between bacterial endophytes}

To determine isolate combinations that have potential for additive and synergistic effects, compatibility between any two endophytes was determined by conducting a modified agar diffusion (or Kirby-Bauer) test. A loopful of $24 \mathrm{~h}$ old culture grown in LB agar was transferred to glass test tubes containing $5 \mathrm{ml}$ of LB broth and incubated for $24 \mathrm{~h}$ on an incubator shaker (New Brunswick Scientific CO., Inc, Edison, NJ 08817 , USA) set at $200 \mathrm{rpm}$ and $30^{\circ} \mathrm{C}$. The concentration of the bacterial suspension was then quantified and adjusted to $\sim 10^{8} \mathrm{CFU} / \mathrm{ml}$. Sterile 8 -mm Whatman number 1 filter paper discs were dipped aseptically into the media suspension of the test endophyte (endophyte 1), and air dried for $30 \mathrm{~min}$. The other endophyte (endophyte 2) was swabbed uniformly on the entire plate using a sterile cotton-tipped applicator. Four discs impregnated with bacteria suspension of endophyte 1 were gently pressed onto the endophyte 2 plated agar surfaces at four equidistant positions using sterile forceps. The plates were incubated at $28 \pm 2{ }^{\circ} \mathrm{C}$ and observed over a period of $72 \mathrm{~h}$ and incompatible endophytes were identified by a zone of inhibition between them.

\section{Evaluation of bacterial endophytes and Phytophthora capsici isolate for sensitivity to mefenoxam}

Three isolates Ps, Psl and Prt that gave best performance on in vitro studies were assessed for sensitivity to mefenoxam by using the turbidometric method. Isolates were prepared in LB broth as described above; $100 \mu \mathrm{l}$ of bacterial suspension was transferred to test tubes containing $5 \mathrm{ml}$ of LB broth previously amended with mefenoxam (Ridomil Gold SL, $480 \mathrm{mg} \mathrm{a.i} \mathrm{ml}^{-1}$ ) at concentrations of $0,10,100$, or $1000 \mu \mathrm{g} \mathrm{ml}^{-1}$. Each fungicide concentration was replicated four times for each isolate. Test tubes were incubated at $30^{\circ} \mathrm{C}$ in an incubator shaker (New Brunswick Scientific CO., Inc, Edison, NJ 08817, USA) set at $200 \mathrm{rpm}$ for $24 \mathrm{~h}$ under ambient light and their concentrations were measured as optical density at $600 \mathrm{~nm}$.

The P. capsici isolate was also tested for sensitivity to mefenoxam using the method of Parra and Ristaino [40]. Mycelial plugs (5 $\mathrm{mm}$ in diameter) of the Phytophthora isolate was obtained from the actively growing margins of a 7-day culture maintained on V8 agar medium and transferred to V8 media amended with mefenoxam (Ridomil Gold SL, $480 \mathrm{mg}^{\mathrm{a} . \mathrm{i} \mathrm{ml}} \mathrm{m}^{-1}$ ) at concentrations of $0,5,10$ and $100 \mu \mathrm{g} \mathrm{ml}^{-1}$ with four replicates for each fungicide concentration. Petri dishes were incubated in an inverted position at $25^{\circ} \mathrm{C}$ for 7 days in ambient light. At day 7 , the mycelial diameters were measured and compared to diameters from non-amended control plates.

Characterization of isolates as sensitive, intermediate, or resistant was based on isolate growth on media amended with different concentrations of mefenoxam as compared to non-amended media. The isolate was regarded as sensitive if the mycelial growth on media amended with $5 \mu \mathrm{g} \mathrm{ml}^{-1}$ of mefenoxam was less than $40 \%$ of the growth on non-amended media; intermediate, if growth on media amended with $5 \mu \mathrm{g} \mathrm{ml}^{-1}$ was greater than $40 \%$ of that on nonamended media, but 
growth on media amended with $100 \mu \mathrm{g} \mathrm{ml}^{-1}$ was less than $40 \%$ of that on nonamended media; if growth on media amended with $100 \mu \mathrm{g} \mathrm{ml}^{-1}$ was greater than $40 \%$ of that on non-amended media the isolate was characterized as resistant [40].

\section{Pathogenicity test of $P$. capsici}

The $P$. capsici isolate used in this study was tested for pathogenicity on seedlings of bell pepper (C. annuum 'California Wonder') in the greenhouse. Surface sterilized pepper seeds were sown in $10-\mathrm{cm}^{2}$ plastic pots containing heat-sterilized Miracle-Gro ${ }^{\circledR}$ potting mix. Plants were fertilized twice a month using Miracle-Gro ${ }^{\circ}$ Water Soluble All-Purpose Plant Food starting two weeks after seedling emergence. Inoculation with $P$. capsici was done eight weeks after germination by drenching the base of each plant with $25 \mathrm{ml}$ zoospore suspension $\left(10^{7}\right.$ zoospores $\left./ \mathrm{ml}\right)$ and control plants were drenched with $25 \mathrm{ml}$ of sterile distilled water. Plants were arranged in a randomized complete block design with six replicates per treatment and one plant per pot as a replicate. The study was repeated once.

Disease severity was evaluated beginning 2 days after inoculation using a scale of $0-5$, in which $0=$ no visible symptoms; $1=$ Slightly wilted with brownish lesions beginning to appear on the stem; $2=$ stem lesions extending to cotyledons and $30 \%$ of plant diseased; $3=$ stem lesions extending to petioles and $50 \%$ of the plant diseased; $4=$ petioles collapse and $80 \%$ of the plant diseased; $5=$ entire plant dead. Re-isolation of the pathogen from diseased plants root, crown, stem, and leaf tissues was done using PARP-amended V8 media. Petri plates were incubated for 7 days at room temperature and colonies with growth characteristic of $P$. capsici were transferred to clarified V8 juice agar. The pathogen was identified based on colony morphology and sporangial characteristics; identification was confirmed using DNA sequence analysis.

\section{Evaluation of bacterial endophytes for biocontrol of P. capsici in bell pepper seedlings}

The study was conducted in a greenhouse at $25 \pm 3^{\circ} \mathrm{C}$. Bell pepper 'California Wonder' seeds were surface-sterilized and treated with the bacterial isolates presented in Table 1 using inoculum concentration of $\sim 10^{8}$ colony forming units (CFU) per ml. Seeds were soaked in inoculum suspension for $1 \mathrm{~h}$ and non-treated control seeds were soaked for $1 \mathrm{~h}$ in sterile water. Treated seeds were sown in $10-\mathrm{cm}^{2}$ plastic pots containing heat-sterilized Miracle-Gro ${ }^{\infty}$ potting mix and arranged in a randomized complete block design with six replicates of individual plants per replicate. Plants were fertilized with Miracle-Gro ${ }^{\infty}$ Water Soluble AllPurpose fertilizer as described above. Eight weeks after germination, plants were inoculated with $P$. capsici and control plants were treated
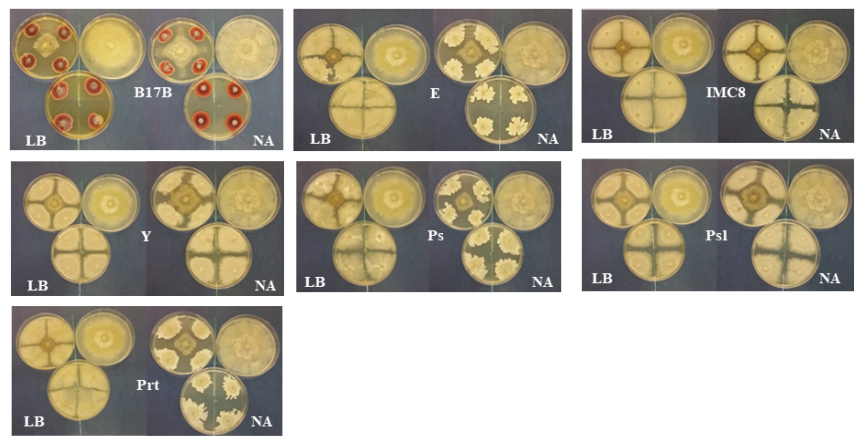

Figure 1: Dual culture assay between bacterial isolates and Phytophthora capsici on Luria-Bertani (LB) agar, and nutrient agar (NA) at day 7 , showing significant inhibition of mycelial growth of the pathogen as compared to the control.

\begin{tabular}{|c|c|c|c|c|}
\hline \multirow{2}{*}{$\begin{array}{c}\text { Treatments } \\
\text { (bacteria) }\end{array}$} & \multicolumn{2}{|c|}{ LB agar growth media } & \multicolumn{2}{|c|}{ Nutrient agar growth media } \\
\hline & $\begin{array}{c}\text { Mycelial } \\
\text { growth (cm) }\end{array}$ & $\begin{array}{l}\text { \% Growth } \\
\text { Inhibition }\end{array}$ & $\begin{array}{c}\text { Mycelial } \\
\text { growth (cm) }\end{array}$ & $\begin{array}{l}\text { \% Growth } \\
\text { Inhibition }\end{array}$ \\
\hline B17B & $1.27 c^{*}$ & $60.89 c$ & $1.84 \mathrm{~g}$ & $51.59 \mathrm{~g}$ \\
\hline$E$ & $0.93 b$ & $71.41 b$ & $1.28 \mathrm{~d}$ & $66.27 d$ \\
\hline IMC8 & $1.19 c$ & $63.39 c$ & $1.43 e$ & $62.50 \mathrm{e}$ \\
\hline $\mathrm{Y}$ & $1.24 \mathrm{c}$ & $61.94 c$ & $1.49 f$ & $60.69 f$ \\
\hline Ps & $0.75 a b$ & $76.96 a b$ & $0.99 b$ & $73.92 b$ \\
\hline Psl & $0.90 a b$ & $72.41 \mathrm{ab}$ & $0.88 a$ & $76.78 a$ \\
\hline Prt & $0.73 a$ & $77.55 a$ & $1.07 \mathrm{c}$ & $71.86 c$ \\
\hline Control & $3.25 d$ & $0.00 \mathrm{~d}$ & $3.81 \mathrm{~h}$ & $0.00 \mathrm{~h}$ \\
\hline
\end{tabular}

*Means followed by the same letter are not significantly different at $5 \%$ level by Fisher's LSD

Table 2: Effect of bacterial endophytes on the mycelial growth of Phytophthora capsici grown on Luria-Bertani (LB) agar and on nutrient agar (NA).

with sterile distilled water as described above. Plants were monitored for disease development and severity using a 0-5 scale described above. The experiment was terminated 12 weeks after germination.

\section{Effects of bacterial endophytes on plant growth and yield of bell peppers}

To evaluate the effects of the bacterial endophytes on the growth and yield of seed-treated bell pepper plants, chlorophyll content, shoot and root length, plant fresh and dry weight, number of fruits per plant and total fruit weight were measured 12 weeks after germination. Chlorophyll content index (CCI) was measured using a handheld chlorophyll content meter (CCM-200 plus ${ }^{\oplus}$, Opti-Sciences, Hudson, NH 03051, USA). Plant samples were dried to constant weight using Binder ${ }^{\circledR}$ Gravity Convection oven (Binder Inc., Bohemia, NY 11716, USA) at $70^{\circ} \mathrm{C}$.

\section{Statistical analysis}

Statistical analyses were performed using IBM $^{\otimes}$ SPSS Statistics ${ }^{\circ}$ version 22. Data were subjected to analysis of variance (ANOVA) and mean comparisons were conducted using Fisher's least significant difference (LSD) at $\mathrm{P} \leq 0.05$. All experiments were repeated.

\section{Results}

\section{Effects of bacterial endophytes on mycelial growth of Phytophthora capsici in LB and NA}

All isolates tested significantly inhibited mycelial growth of $P$. capsici on both LB and NA (Figure 1). Isolates Ps, Psl and Prt caused the highest inhibition on $P$. capsici mycelial growth on both media with $76.96 \%, 72.41 \%$ and $77.55 \%$ growth inhibition on LB, and $73.92 \%$, $76.78 \%$ and $71.86 \%$ growth inhibition on NA (Table 2). The growth media had some effect on the level of inhibition as well as on growth of the bacteria endophytes with E and IMC8 exhibiting higher inhibition on LB than on NA and larger colonies of E on NA than on LB resulting in a higher inhibitory effect on LB agar as compared to NA (Figure 1). Some isolates formed contact with the pathogen and some inhibition on LB media appeared to result from contact between the bacterial isolate and pathogen. While Ps and Prt showed higher inhibition on LB, Psl had higher inhibitory effect on NA (Figure 1).

Quantitative measurements of $P$. capsici mycelial growth and inhibition zones confirmed visual observations; all isolates significantly suppressed P. capsici mycelial growth, but the Bacillus isolates Ps, Psl and Prt displayed superior effect suppressing $P$. capsici growth by more than $70 \%$ on both LB and NA growth media (Table 2). 


\section{Pathogenicity test of Phytophthora capsici isolate on bell pepper}

The $P$. capsici isolate used in this study was highly virulent on 'California Wonder' bell peppers. Dark lesions were noticed on the stem at the soil line within four days of inoculation. Stem lesions rapidly progressed up the plant followed by defoliation and plant death at approximately 10 days after initial disease symptoms were observed (Figure 2).

\section{Effects of selected bacterial endophytes on Phytophthora blight severity in greenhouse.}

Seeds that were not treated with the selected endophytes generated plants that were highly susceptible to P. capsici and showed the highest disease severity, with disease symptoms starting to develop within four days after inoculation with $P$. capsici; plants that were not inoculated with the pathogen did not develop any disease symptoms (Figure 3). Seed treatment with Ps, Psl and Prt reduced disease severities compared to the non-treated control. While all treatments suppressed disease severity, Prt was most effective in suppressing disease severity; Ps and Psl treated plants were not significantly different from Prt-treated plants, but they also were not significantly different from the nontreated control plants at $\mathrm{P} \leq 0.05$ (Figure 3).

\section{Effects of bacterial endophytes on plant growth and yield of bell pepper}

Growth and development of plants as measured by different parameters showed significant differences in shoot height, plant fresh

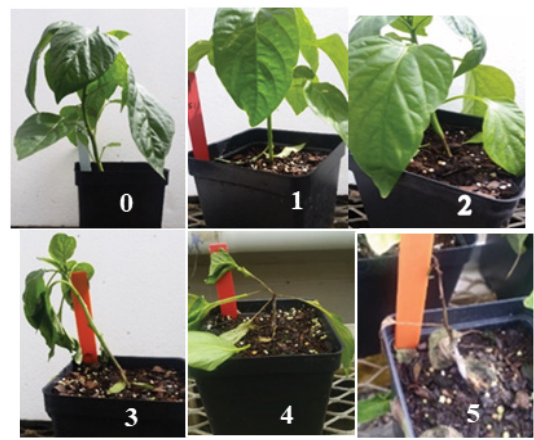

Figure 2: Different levels of Phytophthora blight disease symptoms. Disease severity of $0-5$ scale in which $0=$ no visible symptoms; 1 = Slightly wilted with brownish lesions beginning on the stem; $2=$ Stem lesions extending to cotyledons and $30 \%$ of plant diseased; $3=$ Stem lesions extending to petioles and $50 \%$ of the plant diseased; $4=$ Petioles collapse and $80 \%$ of the plant diseased; $5=$ Entire plant dead

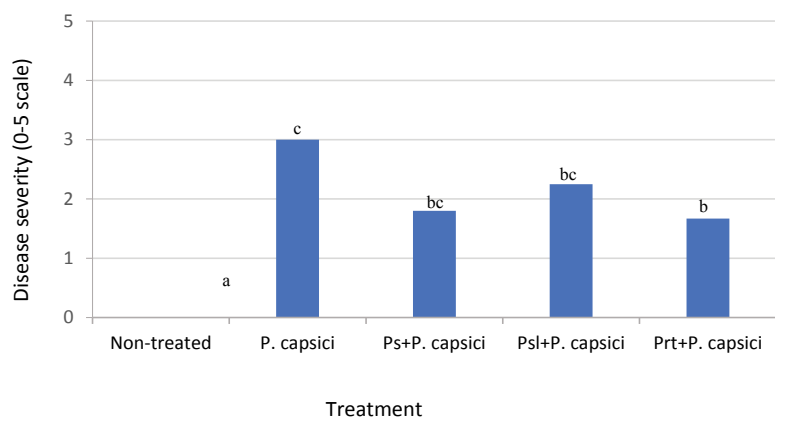

Figure 3: Effect of bacterial endophytes on phytophthora blight severity on bell pepper (California Wonder). Values are means of six replicates. Means followed by the same letter are not significantly different at $5 \%$ level by Fisher's LSD.

\begin{tabular}{|c|c|c|c|c|c|c|c|}
\hline $\begin{array}{c}\text { Treat- } \\
\text { ment }\end{array}$ & $\begin{array}{c}\text { Chlo- } \\
\text { rophyll } \\
\text { content }\end{array}$ & $\begin{array}{c}\text { Root } \\
\text { length } \\
\text { (cm) }\end{array}$ & $\begin{array}{c}\text { Shoot } \\
\text { length } \\
\text { (cm) }\end{array}$ & $\begin{array}{c}\text { Plant } \\
\text { fresh } \\
\text { weight } \\
\text { (g) }\end{array}$ & $\begin{array}{c}\text { Plant } \\
\text { dry } \\
\text { weight } \\
\text { (g) }\end{array}$ & $\begin{array}{c}\text { Number } \\
\text { of fruits/ } \\
\text { plant }\end{array}$ & $\begin{array}{c}\text { Fruit } \\
\text { weight } \\
\text { (g)/plant }\end{array}$ \\
\hline Control & $7.24 a^{*}$ & $32.28 \mathrm{a}$ & $30.45 \mathrm{a}$ & $63.18 \mathrm{a}$ & $7.78 \mathrm{a}$ & $0.75 \mathrm{a}$ & $7.48 \mathrm{a}$ \\
\hline Ps & $9.41 \mathrm{a}$ & $30.92 \mathrm{a}$ & $40.98 \mathrm{~b}$ & $108.58 \mathrm{ab}$ & $8.50 \mathrm{a}$ & $2.20 \mathrm{~b}$ & $48.14 \mathrm{~b}$ \\
\hline Psl & $5.98 \mathrm{a}$ & $28.33 \mathrm{a}$ & $31.00 \mathrm{a}$ & $90.08 \mathrm{ab}$ & $9.03 \mathrm{a}$ & $2.00 \mathrm{~b}$ & $22.55 \mathrm{ab}$ \\
\hline Prt & $8.96 \mathrm{a}$ & $30.73 \mathrm{a}$ & $32.02 \mathrm{a}$ & $110.90 \mathrm{~b}$ & $8.75 \mathrm{a}$ & $2.00 \mathrm{~b}$ & $41.72 \mathrm{~b}$ \\
\hline
\end{tabular}

*Means followed by the same letter are not significantly different at $5 \%$ level by Fisher's LSD

Table 3: Effect of bacterial endophytes on the growth and yield of bell pepper (Capsicum annuum 'California Wonder') under greenhouse conditions.

\begin{tabular}{|c|c|c|c|c|c|c|c|}
\hline \multicolumn{7}{|c|}{ Bacterial isolates } \\
\hline Variables & B17B & E & IMC8 & Y & Ps & Psl & Prt \\
\hline B17B & & - & & + & & - & $\mathrm{nc}$ \\
\hline E & - & & - & - & $\mathrm{nc}$ & - & $\mathrm{nc}$ \\
\hline $\mathrm{IMC8}$ & & - & & $\mathrm{nc}$ & - & - & - \\
\hline Y & + & - & $\mathrm{nc}$ & & - & - & - \\
\hline Ps & & $\mathrm{nc}$ & - & - & & - & $\mathrm{nc}$ \\
\hline Psl & - & - & - & - & - & & - \\
\hline Prt & $\mathrm{nc}$ & $\mathrm{nc}$ & - & - & $\mathrm{nc}$ & - & \\
\hline
\end{tabular}

: Compatible; - Not compatible; nc: Not clear

Table 4: Compatibility between bacterial isolates as determined by modified agar diffusion test.

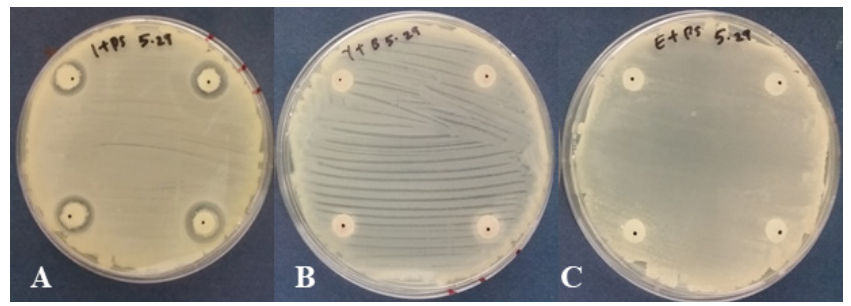

Figure 4: Compatibility tests between combinations of two bacterial endophytes in modified agar diffusion plates. (A) incompatible interaction with clear zone of inhibition, (B) compatible interaction in which two organisms grew together and mixed, (C) unclear interaction with no inhibition zone and not growing together.

weight, fruit yield in number and fruit weight as shown in Table 3. All three Bacillus isolates promoted plant growth in shoot height, fruit number and fruit weight with Ps and Prt being slightly better than Psl (Table 3). However, the chlorophyll contents, root length, and plant dry weight of all treated and non-treated plants were not significantly different at $\mathrm{P} \leq 0.05$ (Table 3).

\section{Compatibility between bacterial endophytes}

Dual cultures between isolates B17B and Y grew well together without inhibiting each other's growth; they were considered compatible. Combinations of isolates B17B and Prt, E and Ps, E and Prt, IMC8 and Y, and Ps and Prt did not show any clear zone of inhibition between organisms and did not mix with each other in their growth. It was unclear whether these organisms were compatible with each other or not (Table 4). Other combinations of isolates such as Prt and B17B, Ps and E, Y and IMC8, E and Ps had a clear zone of inhibition (Figure 4) and were considered incompatible (Table 4).

\section{Sensitivity of Ps, Psl, Prt and P. capsici isolate to mefenoxam}

There was no significant difference in growth of the three Bacillus isolates in media embedded with 10 or $100 \mu \mathrm{g} \mathrm{m}^{-1}$ of mefenoxam compared with the non-embedded medium. Growth on the media amended with $100 \mu \mathrm{g} \mathrm{ml}^{-1}$ was $40 \%$ greater than on non-amended 


\begin{tabular}{|c|c|c|c|c|c|}
\hline \multirow{2}{*}{$\begin{array}{c}\text { Treatment } \\
\left(\mu \mathrm{g} \mathrm{ml}^{-1}\right)\end{array}$} & \multicolumn{3}{|c|}{$\begin{array}{c}\text { BCA concentrations at } \\
\text { OD } 600\end{array}$} & \multicolumn{2}{|c|}{ Phytophthora capsici isolate } \\
\hline & Ps & PsI & Prt & $\begin{array}{l}\text { Mycelial growth } \\
\text { (cm) }\end{array}$ & $\begin{array}{l}\text { \% Growth } \\
\text { Inhibition }\end{array}$ \\
\hline 0 & $0.83 b^{*}$ & $0.82 \mathrm{bc}$ & $0.72 a b$ & $8.44 a$ & $0.00 a$ \\
\hline 5 & NT & NT & NT & $1.37 b$ & $83.78 b$ \\
\hline 10 & $0.72 a$ & $0.76 \mathrm{~b}$ & $0.59 \mathrm{~b}$ & $1.28 \mathrm{c}$ & $84.89 \mathrm{c}$ \\
\hline 100 & $0.79 b$ & $0.86 c$ & $0.78 a$ & $1.08 \mathrm{~d}$ & $87.19 d$ \\
\hline 1000 & $0.67 a$ & $0.64 a$ & $0.65 b$ & NT & NT \\
\hline
\end{tabular}

"Means followed by the same letter are not significantly different at $\mathrm{P} \leq 0.05 ; \mathrm{BCA}$, biological control agents; OD600, optical density measured at $600 \mathrm{~nm}$; NT, not tested

Table 5: Sensitivity of Bacillus isolates Ps, Psl and Prt and Phytophthora capsici to

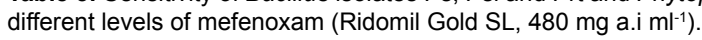

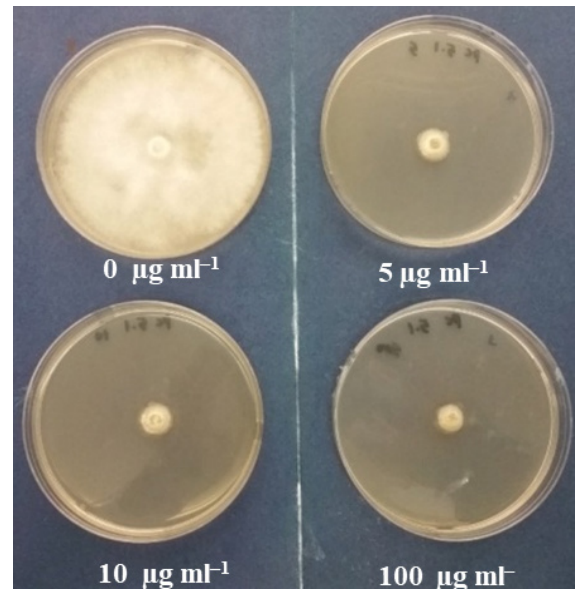

Figure 5: Growth of Phytophthora capsici isolate on media amended with

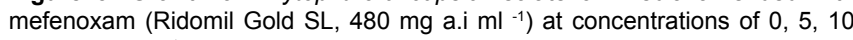
and $100 \mu \mathrm{g} \mathrm{ml}^{-1}$.

medium. Although growth was slightly reduced at $1000 \mu \mathrm{g} \mathrm{ml}{ }^{-1}$ mefenoxam, the difference was less than $40 \%$ of the growth on the nonamended medium (Table 5). Hence, Bacillus isolates Ps, Psl, Prt they were all characterized resistant to mefenoxam [40].

Phytophthora capsici mycelial growth on the medium amended with $5 \mu \mathrm{g} \mathrm{ml}^{-1}$ of mefenoxam was less than $40 \%$ of its growth on the non-amended medium. Mycelial growth decreased significantly with an increase in mefenoxam concentration compared with the nonamended control. Hence the $P$. capsici isolate was characterized to be sensitive to mefenoxam (Table 5 and Figure 5).

\section{Discussion}

Endophytes share an intimate life-long relationship with their host plants. This presents an excellent opportunity for their potential utilization as biological control agents [30]. Their ability to colonize the same ecological niche as plant pathogens [32] make them particularly attractive for use as biological control agents against plant diseases. While some endophytes can colonize a broad range of hosts, some are more specific in their host range [30]. Evaluations of several bacterial endophytes isolated from papaya (Carica papaya), snap bean (Phaseolus vulgaris) and flowering dogwood (Cornus florida) for biological control potential against phytophthora blight in bell pepper showed that all isolates were potential biocontrol agents and significantly inhibited mycelial growth of $P$. capsici on LB and NA media. The degree of inhibition observed varied among isolates and growth media. The growth differences could be due to the nutrient composition of the growth media $[41,42]$. A clear zone of inhibition on $P$. capsici mycelial growth caused by all bacterial isolates suggests the production of secondary metabolites that antagonized growth of P. capsici in culture. Chung et al. [16] reported that Bacillus subtilis isolate ME488 displayed broad-spectrum antibiotic activity in-vitro; it suppressed 39 different plant pathogens belonging to the genera Alternaria, Botrytis, Colletotrichum, Fusarium, Phytophthora, Pythium, Rhizoctonia, and Sclerotinia.

Reports on Bacillus spp. biological control activity against plant pathogens have shown that antibiosis, competition, plant growth promotion and induced systemic resistance were involved [24]. Results obtained from the dual culture assays only show direct antagonism that may be due to the production of antibiotics and/or lytic enzymes. Bacteria in the Enterobacter and Serratia genera are also plant growthpromoting rhizobacteria known to suppress pathogens by producing antimicrobial compounds and competing for space and nutrients [24]. The most effective BCA usually inhibit plant pathogens using multiple mechanisms of action including direct contact, competition for space and nutrients and/or production of secondary metabolites [19]. Results of the in vitro studies suggest that the identification of secondary metabolites as a mechanism of action could be enhanced by the inclusion of different growth media.

The use of Bacillus spp. as biocontrol agents against soil-borne plant pathogens is advantageous because they form endospores, easily colonize plant roots, produce broad-spectrum antibiotics, and promote plant growth [43]. The ability of Bacillus spp to form endospores make them more resistant to harsh environmental conditions, more tolerant to chemical fungicides and easier to formulate into commercial biofungicides with longer viability and shelf-life in comparison to other BCAs that are non-endospore formers [14]. Some Bacillus-based biopesticides such Kodiak, Companion, Serenade, and Rhapsody are currently being sold and used against many important plant pathogens $[44,45]$. Although Enterobacter and Serratia have also been shown to be effective against many soil-borne pathogens $[26,46]$, our in vivo studies focused on only three Bacillus isolates Prt, Ps and Psl that displayed superior effect in suppressing P. capsici growth by more than $70 \%$ on both LB and NA growth media compared to the other four isolates tested (Table 2). The selection of these three isolates was also based on previous bioactivity displayed in vitro and in vivo studies on charcoal rot of snap beans [Jacqueline Joshua, unpublished].

Results from our greenhouse studies with these three Bacillus isolates Prt, Ps and Psl confirmed our in vitro results. Seed treatment with Prt, Ps, and Psl reduced disease severities in bell peppers compared to the non-treated control (Figure 3). While all three treatments suppressed disease severity in greenhouse studies, only Prt was significantly different from the non-treated control; the Ps and Psl treated plants were not significantly different from Prt-treated plants, but they were also not significantly different from the non-treated control plants at $\mathrm{P} \leq 0.05$ (Figure 3). The application of the BCA was done as a onetime seed treatment $1 \mathrm{~h}$ before planting. Although the BCA were re-isolated from the stem tissue of treated plants, it is reasonable to presume that more applications would have provided quantitatively more BCA and been more effective in suppressing disease development. Thus, more studies on the mode and frequency of BCA applications are needed.

In addition to suppressing disease severity, this study showed that all three Bacillus isolates significantly increased plant growth in shoot height, and fruit number and fruit weight with Ps and Prt being slightly better than Psl (Table 3). Chlorophyll contents, root length, and plant dry weight of treated and non-treated plants were not significantly different at $\mathrm{P} \leq 0.05$ (Table 3). Fertilizer application every two weeks 
may have provided abundant nutrients and affected the display of growth benefit from these BCAs. However, increasing the frequency of BCA application would likely improve the growth promoting attributes. Other studies have reported that B. subtilis isolate ME488 significantly suppressed phytophthora blight of red pepper and plants performed better than those treated with fungicides [16]. Similar results include a reduction in phytophthora blight severity in pepper [44] and a reduction in early blight incidence and increased fruit yield in tomato attributed to inoculations with B. subtilis isolates [19]. Many effective BCAs control plant pathogens by stimulating plant defense mechanisms, inducing systemic resistance and/ or plant growth promotion [24]. Increased plant vigor resulting from BCA treatment may have been partly responsible for the reduced severity of Phytophthora blight.

Results from in vitro studies are not always confirmed. Biocontrol agents that show low in vitro inhibition have been reported to significantly reduce the incidence of diseases caused by the same pathogens in greenhouse and field trials. Someya et al. [47] observed that the isolate Serratia marcescens B2 showed negligible inhibition of Fusarium oxysporum $\mathrm{f}$. sp lycopersici in in vitro studies, but reduced the incidence of Fusarium wilt of cyclamen plants by $50 \%$ when applied as soil treatment suggesting that the BCA controls the disease by indirect antagonism. Similarly, Melnick et al. [32] reported that Bacillus cereus isolate BT8 had no antagonism against $P$. capsici in vitro, but suppressed lesion development on cocoa (Theobroma cacao L.) leaves without colonizing them, strongly suggesting induced systemic resistance. Our results from in vitro studies were confirmed by our greenhouse study where the use of seed treatment with BCA suppressed phytophthora blight severity and improved plant growth. Secondary metabolites and other mechanisms for the improvement in plant growth could have been involved. Additional studies are required to verify mechanisms involved in biocontrol activity from these organisms.

Additive and synergistic effects resulting from a combination of two or more bacterial antagonists have been reported [19,48]; such enhanced biocontrol activity is likely due to a combination of various mechanisms of control utilized by the microbial antagonists $[16,48]$. However, the antagonists are required to be compatible to ensure effective and consistent control [19]. Compatibility between various bacterial isolates was evaluated and the results showed that only B17B and $\mathrm{Y}$ were clearly compatible. This observation confirms previous results that demonstrated that B17B and IMC8 were compatible [Emily Rotich, unpublished]. However, in vivo studies for all isolates selected and their mechanisms of action will guide us to determine the best combinations of isolates for synergistic efficacy in biological control.

The phenylamide fungicide metalaxyl has been used for controlling oomycete diseases in several crop species since it was introduced in the 1970s. Excessive use of metalaxyl has led to the rise of metalaxyresistant strains of pathogenic Phytophthora including $P$. capsci and $P$. infestans. Consequently, it was replaced by its more active enantiomer, mefenoxam which has provided effective systemic control of various Phytophthora diseases. Intensive use of mefenoxam has also resulted in the emergence of mefenoxam-resistant strains of $P$. capsici which is now being found in many fields in the United States [40]. Groves and Ristaino [49] observed that the commercial fungicides Ridomil 2E (metalaxyl), Ridomil Gold EC (mefenoxam) at Maneb, Manzate (Mancozeb), Curzate (cymoxanil + mancozeb), and Acrobat MZ (dimethomorph + mancozeb) induced in vitro oospore formation in $P$. infestans and changes in mating type expression after only 2 to 4 weeks of exposure. In this study, the sensitivity to mefenoxam of the $P$. capsici isolate used showed that the isolate was sensitive to the fungicide since its growth in $5 \mathrm{ppm}$ was less than $40 \%$ of its growth on the nonamended media [40] (Figure 5).
Sensitivity of Bacillus isolates Ps, Psl and Prt to mefenoxam at 0 ppm, $10 \mathrm{ppm}, 100 \mathrm{ppm}$, and $1000 \mathrm{ppm}$ showed that all isolates tested were tolerant to mefenoxam even at concentrations higher than the manufacturer's recommended rates. Combining biological control agents with fungicides for plant disease control should reduce the rate of fungicide needed for effective disease management [22]. However, reducing the rate of mefenoxam could results in the development of new pathogenic strains of $P$. capsici. The potential of including BCAs with mefenoxam can be in form of rotations with mefenoxam to reduce the frequency of fungicide applications for a more environmentally friendly, long lasting, consistent, and effective control of $P$. capsici. Similar results on BCA have been reported in other studies [50-54].

\section{Conclusion}

Results presented here indicate that isolates tested in this study have biological control potential against phytophthora blight and may be useful in strategies integrating biological control agents with chemical control of Phytophthora diseases.

\section{Acknowledgements}

Authors would like to thank Drs. Richard Hall and Roger Sauve for their valuable contribution in manuscript reviews. This project was funded by USDA / NIFA Award No. 2010-38821-21477.

\section{References}

1. FAOSTAT (2012) Food and Agriculture Organization of the United Nations.

2. FAOSTAT (2014) Food and Agriculture Organization of the United Nations

3. Kelley WT, Boyhan GE, Harrison KA, Granberry DM, Langston DB, et al. (2009) Commercial pepper production handbook.

4. United States Department of Agriculture Economic Research Service (2008) World bell and chili peppers: Production, 1990-2007.

5. Erwin DC, Bartnicki-Garcia S, Tsao PHT (1995) Phytophthora: its biology taxonomy, ecology and pathology. American Phytopathological Society, St Paul, Minnesota, USA.

6. Pavía SPF, Biles C L, Waugh ME, Waugh KO, Alvarado GR, et al. (2004) Characterization of southern New Mexico Phytophthora capsici Leonian isolates from pepper (Capsicum annuum L.). Revista Mexicana de Fitopatología 22: 82-89.

7. Granke LL, Quesada-Ocampo L, Lamour K, Hausbeck MK (2012) Advances in research on Phytophthora capsici on vegetable crops in the United States. Plant Dis 96: 1588-1600.

8. Hausbeck MK, Lamour KH (2004) Phytophthora capsici on vegetable crops: research progress and management challenges. Plant Dis 88: 1292-1303.

9. Lamour KH, Stam R, Jupe J, Huitema E (2012) The oomycete broad host range pathogen Phytophthora capsici. Mol Plant Pathol 13: 329-337.

10. Satour MM, Butler EE (1967) A root and crown rot of tomato caused by Phytophthora capsici and P. parasitica. Phytopathol 57: 510-515.

11. Roberts PD, Gevens AJ, McGovern RJ, Kucharek TA (2008) Vegetable diseases caused by Phytophthora capsici in Florida. University of Florida, EDIS SP-159:1-4.

12. Hwang BK (2002) Studies of resistance of pepper to Phytophthora blight and its control. Res Plant Dis 8:131-145.

13. Hwang BK, Kim CH (1995) Phytophthora blight of pepper and its control in Korea. Plant Dis 79: 221

14. Kim SG, Jang YL, Kim HY, Koh YJ, Kim YH (2010) Comparison of microbial fungicides in antagonistic activities related to the biological control of phytophthora blight in chili pepper caused by Phytophthora capsici. Plant Pathol J 26: 340-345.

15. Ristaino JB, Johnston SA (1999) Ecologically based approaches to management of Phytophthora blight on bell pepper. Plant Dis 83: 1080-1089.

16. Chung S, Kong H, Buyer JS, Lakshman DK, Lydon J, et al. (2008) Isolation and partial characterization of Bacillus subtilis ME488 for suppression of soilborne pathogens of cucumber and pepper. Appl Microbiol Biotechnol 80: 115-123. 
Citation: Irabor A, Mmbaga MT (2017) Evaluation of Selected Bacterial Endophytes for Biocontrol Potential against Phytophthora Blight of Bell Pepper (Capsicum annuum L.) J Plant Pathol Microbiol 8: 424. doi: 10.4172/2157-7471.1000424

17. Hwang JS, Hwang, BK (1993) Quantitative evaluation of resistance of Korean tomato cultivars to isolates of Phytophthora capsici from different geographic areas. Plant Dis 77: 1256-1259.

18. Cook RJ (1993) Making greater use of introduced microorganisms for biological control of plant pathogens. Annu Rev Phytopathol 31: 53-80.

19. Latha P, Anand T, Ragupathi N, Prakasam V, Samiyappan R (2009)Antimicrobial activity of plant extracts and induction of systemic resistance in tomato plants by mixtures of PGPR strains and Zimmu leaf extract against Alternaria solani. Biol Control 50: 85-93.

20. Harvey SG, Hannahan HN, Sams CE (2002) Indian mustard and ally isothiocyanate inhibit Sclerotium rolfsii. J Am Soc Hortic Sci 127: 27-31.

21. Errakhi R, Bouteau F, Lebrihi A, Barakate M (2007) Evidences of biological control capacities of Streptomyces spp. against Sclerotium rolfsii responsible for damping-off disease in sugar beet (Beta vulgaris L.). World $\mathrm{J}$ Microbiol Biotechnol 23: 1503-1509.

22. Jacobsen BJ, Zidack NK, Larson BJ (2004). The role of Bacillus-based biological control agents in integrated pest management systems: plan diseases. Phytopathol 94: 1272-1275.

23. Brimner TA, Boland GJ (2003). A review of the non-target effects of fungi used to biologically control plant diseases. Agric Ecosyst Environ 100: 3-16.

24. Pal KK, Gardener BM (2006) Biological Control of Plant Pathogens. The Plant Health Instructor 2: 1117-1142.

25. Mao W, Lewis JA, Lumsden RD, Hebbar KP (1998) Biocontrol of selected soilborne diseases of tomato and pepper plants. Crop Prot 17: 535-542.

26. Akköprü A, Demir S (2005) Biological control of Fusarium wilt in tomato caused by Fusarium oxysporum f. sp. Iycopersici by AMF Glomus intraradices and some rhizobacteria. J Phytopathol 153: 544-550.

27. Ji P, Campbell HL, Kloepper JW, Jones JB, Suslow TV, et al. (2006) Integrated biological control of bacterial speck and spot of tomato under field conditions using foliar biological control agents and plant growth-promoting rhizobacteria Biol Control 36: 358-367.

28. Bacon CW, Hinton DM (1996) Symptomless endophytic colonization of maize by Fusarium moniliforme. Can J Bot 74: 1195-1202.

29. Chen C, Bauske EM, Musson G, Rodriguezkabana R, Kloepper JW (1995) Biological control of Fusarium wilt on cotton by use of endophytic bacteria. Biol control 5: 83-91.

30. Hallmann J, Quadt-Hallmann A, Mahaffee WF, Kloepper JW (1997) Bacterial endophytes in agricultural crops. Can J Microbiol 43: 895-914.

31. Carroll G (1988) Fungal endophytes in stems and leaves: from latent pathogen to mutualistic symbiont. Ecol 69: 2-9.

32. Melnick RL, Zidack NK, Bailey BA, Maximova SN, Guiltinan M, et al. (2008) Bacterial endophytes: Bacillus spp. from annual crops as potential biological control agents of black pod rot of cacao. Biol Control 46: 46-56.

33. O'Hanlon KA, Knorr K, Jørgensen LN, Nicolaisen M, Boelt B (2012) Exploring the potential of symbiotic fungal endophytes in cereal disease suppression. Biol Control 63: 69-78.

34. Yuan Y, Feng H, Wang L, Li Z, Shi Y, et al. (2017) Potential of endophytic fungi isolated from cotton roots for biological control against verticillium wilt disease. PloS one 12: e0170557.

35. Backman PA, Sikora RA (2008) Endophytes: an emerging tool for biological control. Biol Control 46: 1-3.

36. Barka EA, Gognies S, Nowak J, Audran JC, Belarbi A (2002) Inhibitory effect of endophyte bacteria on Botrytis cinerea and its influence to promote the grapevine growth. Biol Control 24: 135-142.
37. Costa FG, Zucchi T. D, Melo ISD (2013) Biological control of phytopathogenic fungi by endophytic actinomycetes isolated from maize (Zea mays L.). Braz Arch Biol Technol 56: 948-955.

38. Shiomi HF, Silva HSA, Melo ISD, Nunes FV, Bettiol W (2006) Bioprospecting endophytic bacteria for biological control of coffee leaf rust. Sci Agric 63: 32-39.

39. Jeffers SN (2006) Identifying species of Phytophthora. Department of Entomology, Clemson University, Clemson, SC.

40. Parra G, Ristaino JB (2001) Resistance to mefenoxam and metalaxyl among field isolates of Phytophthora capsici causing Phytophthora blight of bell pepper. Plant Dis 85: 1069-1075

41. Fernando WD, Ramarathnam R, Krishnamoorthy AS, Savchuk SC (2005) Identification and use of potential bacterial organic antifungal volatiles in biocontrol. Soil Biol Biochem 37: 955-964.

42. Vijayakumari SJ, Sasidharannair NK, Nambisan B, Mohandas C (2013) Optimization of media and temperature for enhanced antimicrobial production by bacteria associated with Rhabditis sp. Iran J Microbiol 5: 136.

43. Luna CL, Mariano RLR, Souto-Maior AM (2002) Production of a biocontrol agent for crucifers black rot disease. Braz J Chem Eng 19: 133-140.

44. Brannen PM, Kenney DS (1997) Kodiak® a successful biological-contro product for suppression of soil-borne plant pathogens of cotton. J Ind Microbiol Biotechnol 19: 169-171.

45. McSpadden Gardener BB, Fravel DR (2002) Biological control of plan pathogens: research, commercialization, and application in the USA. Plant Health Prog 10(10.1094)

46. Ordentlich A, Elad Y, Chet I (1987) Rhizosphere colonization by Serratia marcescens for the control of Sclerotium rolfsii. Soil Biol Biochem 19: 747-751.

47. Someya N, Kataoka N, Komagata T, Hirayae K, Hibi T, et al. (2000) Biological control of cyclamen soilborne diseases by Serratia marcescens strain B2. Plant Dis $84: 334-340$

48. Domenech J, Reddy MS, Kloepper JW, Ramos B, Gutierrez-Manero (2006) Combined application of the biological product LS213 with Bacillus, Pseudomonas or Chryseobacterium for growth promotion and biological control of soil-borne diseases in pepper and tomato. Biocontrol 51: 245-258.

49. Groves CT, Ristaino JB (2000) Commercial fungicide formulations induce in vitro oospore formation and phenotypic change in mating type in Phytophthora infestans. Phytopathol 90: 1201-1208.

50. Anand T, Chandrasekaran A, Kuttalam S, Senthilraja G, Samiyappan R (2010) Integrated control of fruit rot and powdery mildew of chilli using the biocontrol agent Pseudomonas fluorescens and a chemical fungicide. Biol Control 52: 1-7.

51. Lima G, De Curtis F, Piedimonte D, Spina AM, De Cicco V (2006) Integration of biocontrol yeast and thiabendazole protects stored apples from fungicide sensitive and resistant isolates of Botrytis cinerea. Postharvest Biol Technol 40: 301-307.

52. Lima G, Castoria R, De Curtis F, Raiola A, Ritieni A, De Cicco V (2011) Integrated control of blue mould using new fungicides and biocontrol yeasts lowers levels of fungicide residues and patulin contamination in apples. Postharvest Bio Technol 60: 164-172.

53. Malathi P, Viswanathan R, Padmanaban P, Mohanraj D, Sunder AR (2002) Compatibility of biocontrol agents with fungicides against red rot disease of sugarcane. Sugar Tech 4: 131-136.

54. Omar I, O'neill TM, Rossall S (2006) Biological control of Fusarium crown and root rot of tomato with antagonistic bacteria and integrated control when combined with the fungicide carbendazim. Plant Pathol 55: 92-99. 